\title{
Identification of a Second rRNA Gene Unit in the Perkinsus andrewsi Genome
}

Article in Journal of Eukaryotic Microbiology · March 2004

DOI: 10.1111/j.1550-7408.2004.tb00553.x · Source: PubMed

CITATIONS

18

3 authors:

\section{Wolf T Pecher}

University of Baltimore

17 PUBLICATIONS 112 CITATIONS

SEE PROFILE

\section{Gerardo R Vasta}

University of Maryland, Baltimore

220 PUBLICATIONS 6,701 CITATIONS

SEE PROFILE
READS

61
José A. Fernández Robledo

Bigelow Laboratory for Ocean Sciences

79 PUBLICATIONS 1,316 CITATIONS

SEE PROFILE

Some of the authors of this publication are also working on these related projects: 


\title{
Identification of a Second rRNA Gene Unit in the Perkinsus andrewsi Genome
}

\author{
WOLF T. PECHER, JOSÉ A. F. ROBLEDO and GERARDO R. VASTA \\ Center of Marine Biotechnology, University of Maryland Biotechnology Institute, University of Maryland, Baltimore, Maryland 21202, USA
}

\begin{abstract}
Perkinsus species are parasitic protozoa of mollusks, currently classified within the Perkinsozoa, a recently established phylum that is basal to the Apicomplexa and Dinozoa. Ribosomal RNA (rRNA) genes and their intergenic spacers have been used to support the taxonomy of Perkinsus species, the description of new species, and to develop molecular probes for their detection and identification. We previously described ultrastructure, behavior in culture, and partial sequence of the rRNA locus of a Perkinsus species isolated from the baltic clam Macoma balthica. The rRNA genes and intergenic spacers of this Perkinsus isolate differed from those described in the currently accepted species to a degree that led to its designation as a new species, Perkinsus andrewsi. In this study, we identify an additional rRNA gene unit (rRNA-B) in the $P$. andrewsi holotype, and report the complete sequences of both rRNA gene units. Except for the 5.8S, all regions of the rRNA-B gene unit exhibited sequence differences from that initially described (rRNAA). Each rRNA gene unit is arranged in a "head-to-tail" tandem repeat. This is the first report demonstrating two distinct rRNA units in a Perkinsus species.
\end{abstract}

Key Words. ICS, IGS, ITS, LSU, Macoma balthica, SSU.

\section{P} ERKINSUS species (Perkinsozoa, Perkinsea) (Norén, Moestrup, and Rehnstam-Holm 1999) are protistan parasites of mollusks, often associated with disease. Perkinsus marinus was initially classified as a fungus within the genus Dermocystidium (D. marinum; Mackin, Owen, and Collier 1950). Ultrastructural studies on its zoospore stage, however, revealed morphological characteristics that resemble those of apicomplexan parasites, leading to the establishment of a new genus Perkinsus within the phylum Apicomplexa and renaming $D$. marinum as $P$. marinus (Levine 1978). Taxonomic affinities of $P$. marinus with Parvilucifera infectans, a protistan parasite of dinoflagellates, led Norén, Moestrup, and Rehnstam-Holm (1999) to establish the new phylum Perkinsozoa that now includes the genera Perkinsus, Parvilucifera, and Cryptophagus (Brugerolle 2002; Norén, Moestrup, and Rehnstam-Holm 1999). Based on sequence comparisons of actin and small subunit (SSU) ribosomal RNA (rRNA) genes, Siddal et al. (1997) suggested that Perkinsus species were closely related to the Dinozoa, and should be excluded from the Apicomplexa. Recent phylogenetic studies that included protein (actin and tubulins) and SSU rRNA gene phylogenies supported this view, and it has been proposed that Perkinsus is the earliest divergent group from the Dinozoa ( $\mathrm{Ku}-$ vardina et al. 2002; Saldarriaga et al. 2003).

Sequences of rRNA genes and intergenic regions have significantly contributed to the taxonomic characterization of Perkinsus species (Fong et al. 1993; Goggin 1994; Goggin and Baker 1993), to support new species designations (Coss et al. 2001; Kotob et al. 1999), and to develop molecular probes for their detection and identification (Coss et al. 2001; de la Herrán et al. 2000; Marsh, Gauthier, and Vasta 1995; Penna, Khan, and French 2001; Robledo, Coss, and Vasta 2000; Robledo et al. 1998; 1999; 2002; Yarnall et al. 2000).

The organization of the rRNA gene cluster of Perkinsus species differs from that of most eukaryotes described so far. Unlike the typical eukaryotic rRNA gene cluster, in Perkinsus species the 5S gene is linked to the SSU rRNA gene (Coss et al. 2001; de la Herrán et al. 2000; Marsh, Gauthier, and Vasta 1995). This was corroborated by the characterization of the complete rRNA gene units of $P$. atlanticus and $P$. marinus (Robledo et al. 2002; JAFR and GRV, unpubl.). In these species, the rRNA gene unit consists of the following regions: $5 \mathrm{~S}$, intergenic spacer (IGS), SSU, internal transcribed spacer (ITS) 1, 5.8S, ITS2, and large subunit (LSU). Within a rRNA gene cluster, the rRNA gene units are arranged as "head-to-tail", tandem repeats that are separated by intercluster spacers (ICS)

Corresponding Author: G. R. Vasta-Telephone number: 410-2348826; FAX number: 410-234-8896; E-mail: vasta@umbi.umd.edu (de la Herrán et al. 2000; Robledo et al. 2002). A similar rRNA gene organization was described for some fungi and algae (reviewed by Kawai et al. 1995), and the apicomplexan parasite Toxoplasma (Guay et al. 1992). However, in other Apicomplexa, such as Plasmodium, Babesia, Theileria, and Cryptosporidium, instead of the typical tandem organization of multiple rRNA gene units, these (from one to ten copies) are unlinked, and further, the 5S is unlinked to the other rRNA genes of each rRNA unit. In some species, a higher level of complexity of the rRNA genes has been identified: the multiple rRNA gene units may not be identical, and up to seven distinct rRNA units have been described (Dame and McCutchan 1983; Gardner et al. 2002; Le Blancq et al. 1997; Reddy et al. 1991). In P. falciparum four rRNA gene units (A, B, C, and D) have been reported, which transcribe at least two life stage-specifically expressed rRNA types (A and S) (Gunderson et al. 1987; McCutchan et al. 1988). Recently, a fifth rRNA gene unit has been identified that is almost identical to the S-type rRNAs in the SSU and 5.8S gene sequences, but differs significantly in the LSU gene sequence from the LSU sequences of the A- and S-type rRNAs (Gardner et al. 2002). The presence of two distinct SSU and LSU gene sequences was also reported in dinoflagellate species within the genus Alexandrium (Scholin, Anderson, and Sogin 1993; Scholin et al. 1994; Yeung et al. 1996).

We previously described ultrastructure, behavior in culture, and partial sequence of the rRNA locus of a Perkinsus species isolated from the baltic clam Macoma balthica (Coss, Robledo, and Vasta 2001; Coss et al. 2001). The degree of difference of all rRNA genes and intergenic regions examined was comparable to or greater than differences between the currently accepted Perkinsus species, which led to the designation of the $M$. balthica isolate as $P$. andrewsi (Coss et al. 2001). Here, we describe an additional $P$. andrewsi rRNA gene unit (rRNA-B), distinct from the one initially identified (referred to as rRNAA herein), and we report the complete characterization of the two rRNA gene units (rRNA-A and rRNA-B). This is the first report for the presence of two distinct rRNA gene units in a Perkinsus species.

\section{MATERIALS AND METHODS}

$P$. andrewsi cell culture. The $P$. andrewsi monoclonal holotype culture (PAND-A8-4a, ATCC 50807; Coss et al. 2001) was maintained in DMEM:HAM's (1:2) medium supplemented with $5 \%(\mathrm{v} / \mathrm{v})$ fetal bovine serum (Gauthier and Vasta 1995). It was subjected to two rounds of subcloning by limiting dilution as described elsewhere (Coss, Robledo, and Vasta 2001; Gauthier and Vasta 1995). Briefly, for each round of subcloning a cell suspension at a density of 3 cells $/ \mathrm{ml}$ was plated into 96- 
Table 1. PCR primers for the amplification of rRNA genes and intergenic regions of Perkinsus andrewsi and probe design for Southern analysis.

\begin{tabular}{|c|c|c|c|}
\hline Primer & Sequence $\left(5^{\prime}-3^{\prime}\right)$ & Specificity & Reference \\
\hline M6 & TTCATCACTTGAGTTGCG & IGS-B & This study \\
\hline M8 & GCGAAAATTGACTTTCAGGTCG & IGS-B & This study \\
\hline NTS2 & ATGAGCCATTCGCAGTTTCGCC & SSU & Robledo et al. 1999 \\
\hline NTS6 & ATTGTGTAACCACCCCAGGC & IGS-A & Coss et al. 2001 \\
\hline NTS7 & AAGTCGAATTGGAGGCGTGGTGAC & IGS-A & Coss et al. 2001 \\
\hline UPRA & AACCTGGTTGATCCTGCCAGT & SSU & Medlin et al. 1988 \\
\hline UPRB & TGATCCTTCTGCAGGTTCACCTAC & SSU & Medlin et al. 1988 \\
\hline
\end{tabular}

well plates with $100 \mu \mathrm{l} /$ well, $50 \mu \mathrm{l}$ of $0.2-\mu \mathrm{m}$ filter-sterilized culture medium added, and incubated at $28{ }^{\circ} \mathrm{C}$ for $24 \mathrm{~h}$. Wells containing single cells were identified using an inverted microscope. After an additional incubation of $5 \mathrm{~d}$, the entire content of each selected well was transferred to single wells in a 24well plate. Between each round of subcloning the cultures were incubated for 3 to 4 days.

PCR amplification, cloning, and sequencing. DNA from in vitro-propagated $P$. andrewsi (PAND-A8-4a) was extracted using the DNeasy Tissue kit (QIAGEN, Valencia, CA). The IGS was PCR-amplified with the primers NTS1 and NTS2 under PCR conditions that have been optimized for the amplification of the IGS of P. marinus (Robledo et al. 1999). To obtain complete rRNA gene unit sequences, three different amplicons containing rRNA genes and intergenic regions were generated by PCR. Primers used are listed in Table 1, and their relative positions within the rRNA gene unit are shown in Fig. 1. Partial IGS and the complete SSU were amplified using the primer M8 (this study), and UPRB from Medlin et al. (1988). Partial IGS, the complete SSU, and the complete ITS1-5.8S-ITS2 region were amplified using the IGS specific primers NTS7 (Coss et al. 2001) and M8 (this study) and the primer PMITS3 (this study). Partial IGS, the complete SSU, the ITS1-5.8S-ITS2 region, and the LSU-ICS-5S region were amplified using the primers NTS6 and M5 (Coss et al. 2001; this study) and UPRA (Medlin et al. 1988).

PCR products were separated by electrophoresis using $1 \%$ agarose gels and visualized by staining with ethidium bromide (EtBr) $(0.5 \mu \mathrm{g} / \mathrm{ml})$. Amplicons were gel-purified using the QIAquick Gel Extraction kit (QIAGEN). Purified amplicons were cloned using the Promega pGEMII vector system (Promega

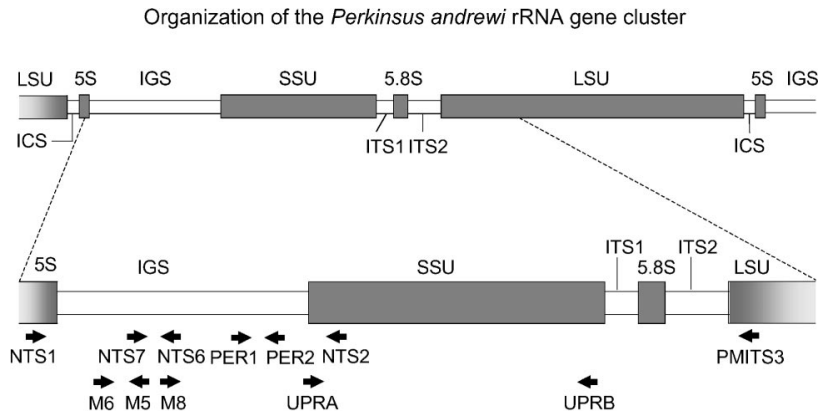

Fig. 1. Localization of primers (arrows) used for the amplification of rRNA genes and intergenic regions of Perkinsus andrewsi. ICS, intercluster spacer; IGS, intergenic spacer; ITS, internal transcribed spacer; LSU, large subunit; SSU, small subunit.
Corporation, Madison, WI). At least three clones obtained from 10 PCR amplifications containing the IGS, eight clones obtained from at least two PCR amplifications containing partial sequence of the IGS and the complete SSU region, two clones from two PCR amplifications containing partial sequence of the IGS and the complete SSU-ITS1-5.8S-ITS2 region, and one clone from one PCR amplification containing partial sequence of the IGS and the complete SSU-ITS1-5.8S-ITS2-LSU-ICS$5 \mathrm{~S}$ region were sequenced using additional internal primers.

To assess the potential intraclonal IGS variability, IGS amplicons were generated in five independent PCR amplifications using the primers NTS1 and NTS2 (Robledo et al. 1999) under the following optimized PCR conditions: $94{ }^{\circ} \mathrm{C}$ for $3 \mathrm{~min}$, followed by 30 cycles of $94{ }^{\circ} \mathrm{C}$ for $1 \mathrm{~min}, 65{ }^{\circ} \mathrm{C}$ for $45 \mathrm{~s}, 72{ }^{\circ} \mathrm{C}$ for $1 \mathrm{~min}$, with a final extension at $72{ }^{\circ} \mathrm{C}$ for $10 \mathrm{~min}$. PCR products were size-separated, gel-purified, cloned, and sequenced as described above. For each amplicon, at least nine clones were sequenced.

The rRNA sequences of $P$. andrewsi (accession number AF102171), P. marinus (AF497479), P. atlanticus (AF140295), P. chesapeaki (isolate G117) (AF042707 and AF091541), Perkinsus species isolated from Mya arenaria (ATCC 50864) (AF440464, AF440465, AF440466, and AF440467), and Tagelus plebeius (ATCC 50866, AF440468, AF440469, AF440470, and AF440471) were obtained from GenBank ${ }^{\text {(in }}$ Sequences were aligned using ClustalW with default parameters (Thompson, Higgins, and Gibson 1994). Because of expected low sequence identities between intergenic regions, all IGS, ITS1, ITS2, and ICS sequences were anchored with $P$. andrewsi SSU sequence (AF102171). A similarity search for the $P$. andrewsi ICS sequences was performed using BLASTn (Altschul et al. 1990).

Assessment of IGS representation. To assess the relative representation of the two IGSs identified, serially diluted $P$. andrewsi genomic DNA was amplified with the primers NTS1 and NTS2 (Robledo et al. 1999) using the optimized PCR conditions. PCR products were separated and visualized as described above. Gel photographs (Polaroid black and white instant pack film 667, Polaroid, Waltham, MA) were scanned at high resolution $(1,200 \mathrm{dpi})$. The intensity of amplicons on the digital images was analyzed using the software NIH Image 1.62 (developed at the National Institutes of Health and available at http://rsb.info.nih.gov/nih-image/). Because the intensity of EtBr-stained amplicons is proportional to their length (Sambrook and Russell 2001; Tanabe et al. 2002), intensity values for smaller amplicons were normalized to the length of the largest amplicon by the ratio of the size of the largest amplicon to the size of the amplicon of interest. 
Single-cell PCR. A $P$. andrewsi cell suspension was incubated in fluid thioglycollate medium (FTM) for one week (Ray 1952). During the incubation in FTM, Perkinsus species trophozoites enlarge and arrest in the prezoosporagium stage. To obtain single cells, $5 \mu \mathrm{l}$ of the FTM-treated culture was diluted 10 -fold in distilled water. This cell suspension was further serially diluted in $50 \mu \mathrm{l}$ of distilled water in a 96-well plate until wells with single cells were identified under an inverted microscope. The entire content of wells containing single cells was transferred to a $0.5-\mathrm{ml}$ thin-walled microcentrifuge tube and frozen at $-20{ }^{\circ} \mathrm{C}$. The samples were thawed, dried in a speed vacuum concentrator, resuspended in distilled water to a final volume of $22 \mu \mathrm{l}$, boiled for $3 \mathrm{~min}$, and the IGS amplified as described above. The PCR products were tested by PCR for the presence of $P$. andrewsi IGS sequences using primers specific for the IGS-A (NTS6 and NTS 7) (Coss et al. 2001) and IGSB (M5; this study), and universal primers for amplification of the IGS (NTS1) (Robledo et al. 1999) (Table 1).

Southern analysis. High molecular weight $P$. andrewsi genomic DNA was extracted following Green (1997) with slight modifications. Briefly, approximately $3.0 \times 10^{6}$ cells of a logphase culture were lysed over night at $55{ }^{\circ} \mathrm{C}$ in sucrose/proteinase $\mathrm{K}$ cell lysis buffer $(150 \mathrm{mM} \mathrm{NaCl}, 15 \mathrm{mM}$ Na citrate, $1 \mathrm{mM}$ EDTA, $200 \mu \mathrm{g} / \mathrm{ml}$ proteinase $\mathrm{K}, 1 \%$ (w/v) sodium dodecyl sulphate (SDS), 27\% (w/v) sucrose). DNA was extracted with phenol:chloroform:isoamyl alcohol $(25: 24: 1)$, precipitated with isopropanol, washed with $70 \%$ ethanol and resuspended in TE buffer (10 mM Tris, $1 \mathrm{mM}$ EDTA, $\mathrm{pH}$ 8.0). To remove RNA, the sample was treated with $1 \mathrm{mg} / \mathrm{ml}$ RNAse A, and the DNA precipitated with ice-cold ethanol (100\%). Four micrograms of $P$. andrewsi DNA were digested with the restriction enzymes BamHI, BstEII, EcoRI, and ScaI (New England BioLabs Inc., Beverly, MA; Promega, Invitrogen Corp., Carlsbad, CA) following the manufacturers' recommendations. Controls consisted of plasmids containing the IGS-A and IGS-B (200 ng and $20 \mathrm{ng}$, respectively), and uncut $P$. marinus genomic DNA $(4 \mu \mathrm{g})$. DNA digests and control samples were fractionated on a $0.8 \%$ agarose gel, stained with $\mathrm{EtBr}$, and transferred onto a Nylon membrane (Hybond XL, Amersham Biosciences Corp., Piscataway, NJ) by capillary blotting (Sambrock and Russell 2001). The membrane was hybridized in an aqueous prehybridization/hybridization solution $(450 \mathrm{mM} \mathrm{NaCl}, 45 \mathrm{mM}$ Na citrate, 2 mg/l Ficoll 400, 2 mg/l polyvinylpyrrolidone, 2 $\mathrm{mg} / \mathrm{l}$ bovine serum albumin, $0.1 \%$ (w/v) SDS, $100 \mu \mathrm{g} / \mathrm{ml} \mathrm{salm}-$ on sperm DNA) at $68{ }^{\circ} \mathrm{C}$ overnight (Brown 1993) with either an IGS-A specific probe (probe A, $290 \mathrm{bp}$ ), an IGS-B specific probe (probe B, $305 \mathrm{bp}$ ), or a probe specific to Perkinus species IGSs (probe PER, $315 \mathrm{bp}$ ). The membrane was stripped two to three times by boiling in $0.1 \%$ (w/v) SDS between hybridizations. Probes A and PER were generated by PCR from a plasmid containing the IGS-A using primers specific for the IGSA (NTS6 and NTS7) and primers specific to Perkinsus species (PER1 and PER2, Robledo et al. 2002). Probe B was generated by PCR from a plasmid containing the IGS-B using IGS-B specific primers (M5 and M6, this study). The probes were labeled with $\left[\alpha^{32} \mathrm{P}\right]$ dCTP using rediprime ${ }^{(1 \mathrm{ND})}$ II (Amersham Biosciences Corp.). Autoradiographic film (Kodak X-Omat Blue XB-1, Rochester, NY) was exposed to the nylon membrane for $30 \mathrm{~min}$ at room temperature after hybridization with probe $\mathrm{A}, 3 \mathrm{~h}$ at $-80{ }^{\circ} \mathrm{C}$ after hybridization with probe $\mathrm{B}$, and $1 \mathrm{~h}$ at room temperature after hybridization with probe PER. To demonstrate specificity of the probes, exposures were extended to $16-$ $18 \mathrm{~h}$ at $-80{ }^{\circ} \mathrm{C}$.

\section{RESULTS}

Sequence of the rRNA locus. PCR amplification of $P$. andrewsi DNA using primers that flank the IGS region yielded a

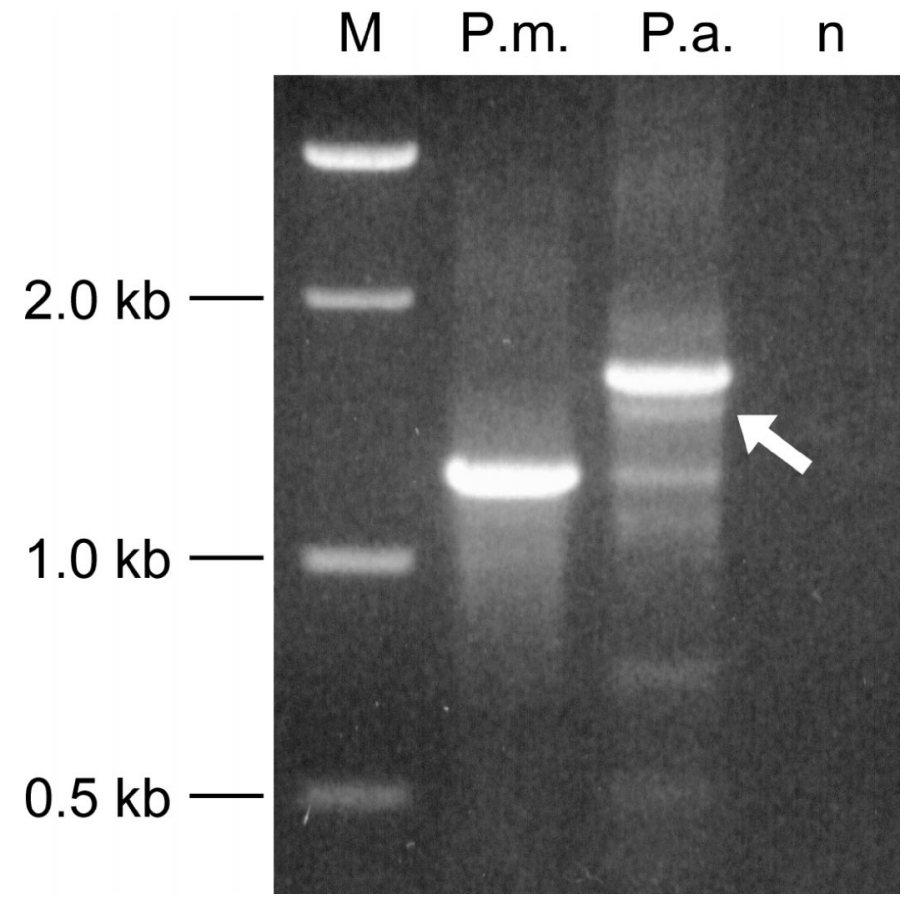

Fig. 2. Agarose gel electrophoresis of PCR-amplified products with IGS primers. P.a., Perkinsus andrewsi DNA; P.m., P. marinus DNA; $\mathrm{n}$, negative control, PCR reaction contained the same mixture as the other PCR reactions except DNA was substituted with sterile distilled water; $\mathrm{M}, 1 \mathrm{~kb}$ DNA ladder. Note the additional $1.5-\mathrm{kb}$ amplicon (arrow) in $P$. andrewsi, which corresponds to the later identified intergenic spacer of the rRNA-B gene unit.

prominent amplicon of the expected size (1,670 bp) and a smaller additional product (1,540 bp) (Fig. 2). Sequence analysis of the smaller amplicon revealed sequences of the $5 \mathrm{~S}$ and SSU rRNA in the $3^{\prime}$ and 5' ends, respectively, suggesting that this sequence represented an IGS. Alignment analysis showed that this IGS sequence (hereafter IGS-B) differed in 419 positions $(27.3 \%)$ from the previously described $P$. andrewsi IGS sequence (Coss et al. 2001; hereafter IGS-A).

PCR amplification using primers based on the IGS-B (primer M8) and primers based on conserved regions in the $3^{\prime}$ end of the SSU (primer UPRB) and the $5^{\prime}$ end of the LSU (primer PMITS3) resulted in amplicons of 2,522 bp and 3,274 bp, respectively. Sequence analysis showed that both amplicons contained part of the IGS-B, and a complete SSU rRNA sequence. In addition, the 3,274-bp amplicon contained an ITS1-5.8SITS2 sequence, and sequences present in the $5^{\prime}$ end of the LSU. Sequence analysis of clones that contained the IGS-B sequence and the SSU-ITS-1-5.8S-ITS2 region showed that except for the $5.8 \mathrm{~S}$, all sequences of the rRNA genes and intergenic regions associated with the IGS-B differed from the initially described $P$. andrewsi rRNA genes and intergenic regions. This demonstrated contiguity of the newly described sequences.

To isolate and characterize the LSU, the 5S, and the ICS of both rRNA gene units, amplicons were generated by PCR using primers specific for the IGS-A (primer NTS6) and IGS-B (primer M5), and a primer based in a conserved region of the $5^{\prime}$ end of the SSU (primer UPRA) (Fig. 1). The obtained amplicons were 7,042 bp and 6,881 bp long, respectively. Both amplicons contained a partial IGS sequence, the complete SSU, the ITS15.8-ITS2 region, the complete LSU, and a region consisting of the ICS and the 5S that were contiguous with the LSU and the IGS, respectively. The LSU sequences of both gene units were 
Table 2. Comparison of the rRNA genes and intergenic spacers between Perkinsus andrewsi A and B rRNA units, $P$. atlanticus, $P$. marinus, and $P$. chesapeaki (isolate G117).

\begin{tabular}{lccc}
\hline \hline & \multicolumn{3}{c}{ Percent identity of the 5S } \\
\cline { 2 - 4 } & $\begin{array}{c}P . \\
\text { andrewsi } \\
\end{array}$ & $\begin{array}{c}\text { P. } \\
\text { rRNA-B }\end{array}$ & $\begin{array}{c}\text { atlanticus } \\
\text { marinus }\end{array}$ \\
\hline P. andrewsi rRNA-A & 99.2 & 95.2 & 97.5 \\
$P$. andrewsi rRNA-B & & 96.0 & 98.3 \\
$P$. atlanticus & & & 97.6
\end{tabular}

\begin{tabular}{lccc} 
& \multicolumn{3}{c}{ Percent identity of the IGS } \\
\cline { 2 - 4 } & $\begin{array}{c}P . \\
\text { andrewsi } \\
\end{array}$ & $\begin{array}{c}\text { P. } \\
\text { rRNA-B }\end{array}$ & $\begin{array}{c}\text { atlanticus } \\
\text { marinus }\end{array}$ \\
\hline P. andrewsi rRNA-A & 72.7 & 49.1 & 50.8 \\
$P$. andrewsi rRNA-B & & 52.3 & 51.2 \\
$P$. atlanticus & & & 72.2
\end{tabular}

$P$. atlanticus 72.2

\begin{tabular}{lcccc} 
& \multicolumn{4}{c}{ Percent identity of the SSU } \\
\cline { 2 - 5 } & $\begin{array}{c}P . \\
\text { andrewsi } \\
\end{array}$ & $\begin{array}{c}\text { P. } \\
\text { rRNA-B }\end{array}$ & $\begin{array}{c}\text { atlanticus } \\
\text { marinus }\end{array}$ & $\begin{array}{c}\text { P. } \\
\text { chesapeaki }\end{array}$ \\
\hline P. andrewsi rRNA-A & 99.8 & 99.1 & 98.5 & 99.6 \\
$P$. andrewsi rRNA-B & & 99.3 & 98.7 & 99.7 \\
$P$. atlanticus & & & 99.3 & 99.0 \\
$P$. marinus & & & & 98.5
\end{tabular}

Percent identity of the ITS1

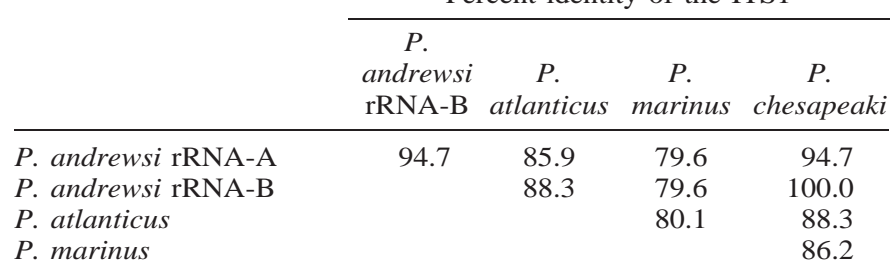

Percent identity of the $5.8 \mathrm{~S}$

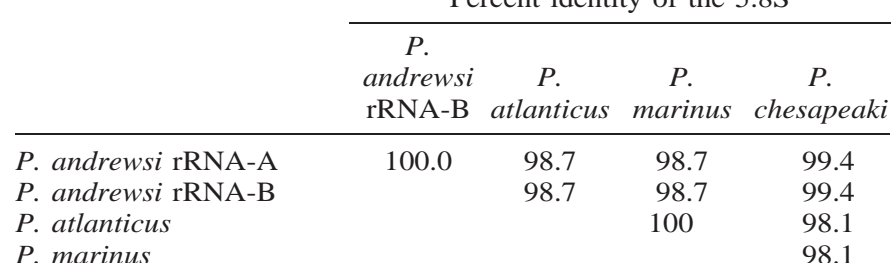

Percent identity of the ITS2

\begin{tabular}{cccc}
\hline $\begin{array}{c}P . \\
\text { andrewsi }\end{array}$ & $P$. & $P$. & $P$. \\
rRNA-B & atlanticus & marinus & chesapeaki \\
\hline \multirow{2}{*}{91.8} & 79.2 & 79.1 & 82.3 \\
& 78.4 & 80.2 & 99.7 \\
& & 92.5 & 79.4 \\
& & & 80.2
\end{tabular}

Percent identity of the LSU

\begin{tabular}{ccc}
\hline \multicolumn{2}{c}{ P. } & \\
andrewsi & $P$. & $P$. \\
rRNA-B & atlanticus & marinus \\
\hline 99.1 & 97.9 & 98.0 \\
& 98.2 & 98.2 \\
& & 98.8 \\
\hline
\end{tabular}

Table 2. Continued

\begin{tabular}{lccc}
\hline \hline & \multicolumn{3}{c}{ Percent identity of the ICS } \\
\cline { 2 - 4 } & $\begin{array}{c}P . \\
\text { andrewsi }\end{array}$ & $\begin{array}{c}\text { P. } \\
\text { rRNA-B }\end{array}$ & $\begin{array}{c}\text { atlanticus } \\
\text { marinus }\end{array}$ \\
& 62.1 & 31.5 & 31.8 \\
$P$. andrewsi rRNA-A & & 29.8 & 29.3 \\
$P$. andrewsi rRNA-B & & & 61.1 \\
$P$. atlanticus & & & \\
\hline
\end{tabular}

3,528 bp long and showed $99.1 \%$ identity. The $5 \mathrm{~S}-\mathrm{A}$ and $-\mathrm{B}$ sequences were $121 \mathrm{bp}$ long and to $99.2 \%$ identical. The ICSs of the rRNA-A and -B units differed both in size and sequence. The ICS-A (124 bp) and the ICS-B (109 bp) differed in 47 positions $(37.9 \%$, based on the length of ICS-A). A database search for both ICS using BLASTn (Altschul et al. 1990) failed to identify similar sequences. Consensus sequences of the LSUISC-5S region of the rRNA-A unit and the complete rRNA-B unit were deposited at GenBank (AYM05327 and AY305326, respectively).

Sequence comparison of the $P$. andrewsi rRNA genes and intergenic spacer with Perkinsus species and isolates. Sequence comparisons of the rRNA genes and intergenic regions of the $P$. andrewsi rRNA-A and -B gene units, $P$. marinus, $P$. atlanticus, and $P$. chesapeaki are summarized in Table 2. Sequence differences were most pronounced in the IGS and the ICS.

In Perkinsus species isolated from $M$. arenaria and $T$. plebeius, four distinct sequence types of the ITS1-5.8S-ITS2 region were reported (Dungan et al. 2002). One of the four reported variant types of ITS1-5.8S-ITS2 sequences (AF440465 and AF440469) of each Perkinsus species isolated from M. arenaria and $T$. plebeius showed $100 \%$ identity with the ITS15.8S-ITS2 region of $P$. andrewsi rRNA-A. The $P$. andrewsi unit B ITS1-5.8S-ITS2 sequence showed high sequence identity (99.6\%) to the respective $P$. chesapeaki sequence, and to two of the four variant sequence types (AF440464, AF440467, AF440468, and AF440471) of each Perkinsus species isolated from $M$. arenaria and T. plebeius with $100 \%, 99.9 \%, 99.6 \%$ and $100 \%$ identity, respectively. One variant sequence form of the ITS1-5.8S-ITS2 sequences from the Perkinsus species from T. plebeius (AF440470) showed high sequence identity towards the $P$. andrewsi unit A sequence at the $3^{\prime}$ end and high sequence identities towards $P$. chesapeaki and the $P$. andrewsi unit $\mathrm{B}$ sequence at the $5^{\prime}$ end (Fig. 3).

Assessment of representation of the rRNA-A and rRNA$B$ units. The relative amounts of $P$. andrewsi IGS-A and IGSB amplicons varied with the amplification conditions selected during the PCR optimization (Fig. 2, 4). A semi-quantitative assessment carried out by titration of genomic DNA template showed that the detection limit for IGS-A and IGS-B was between 0.5-pg and 5-pg of genomic DNA (Fig. 4). Analysis of the intensities of the amplicons obtained under the optimized PCR conditions showed that the intensity of the IGS-B amplicon was approximately $90 \%$ of the intensity of the IGS-A.

Single-cell IGS-specific PCR. The $P$. andrewsi clonal culture characterized in this study had been subjected to two rounds of subcloning (Coss, Robledo and Vasta 2001). However, to rule out the possibility that rRNA-A and rRNA-B originated in different (non-clonal) $P$. andrewsi cells, we carried out PCR amplification of IGS-A and IGS-B from single $P$. andrewsi cells, using primers specific for IGS-A (Coss et al. 2001) and IGS-B (this study). In each single cell, both primer sets yielded amplicons of the expected sizes for IGS-A and IGS-B 


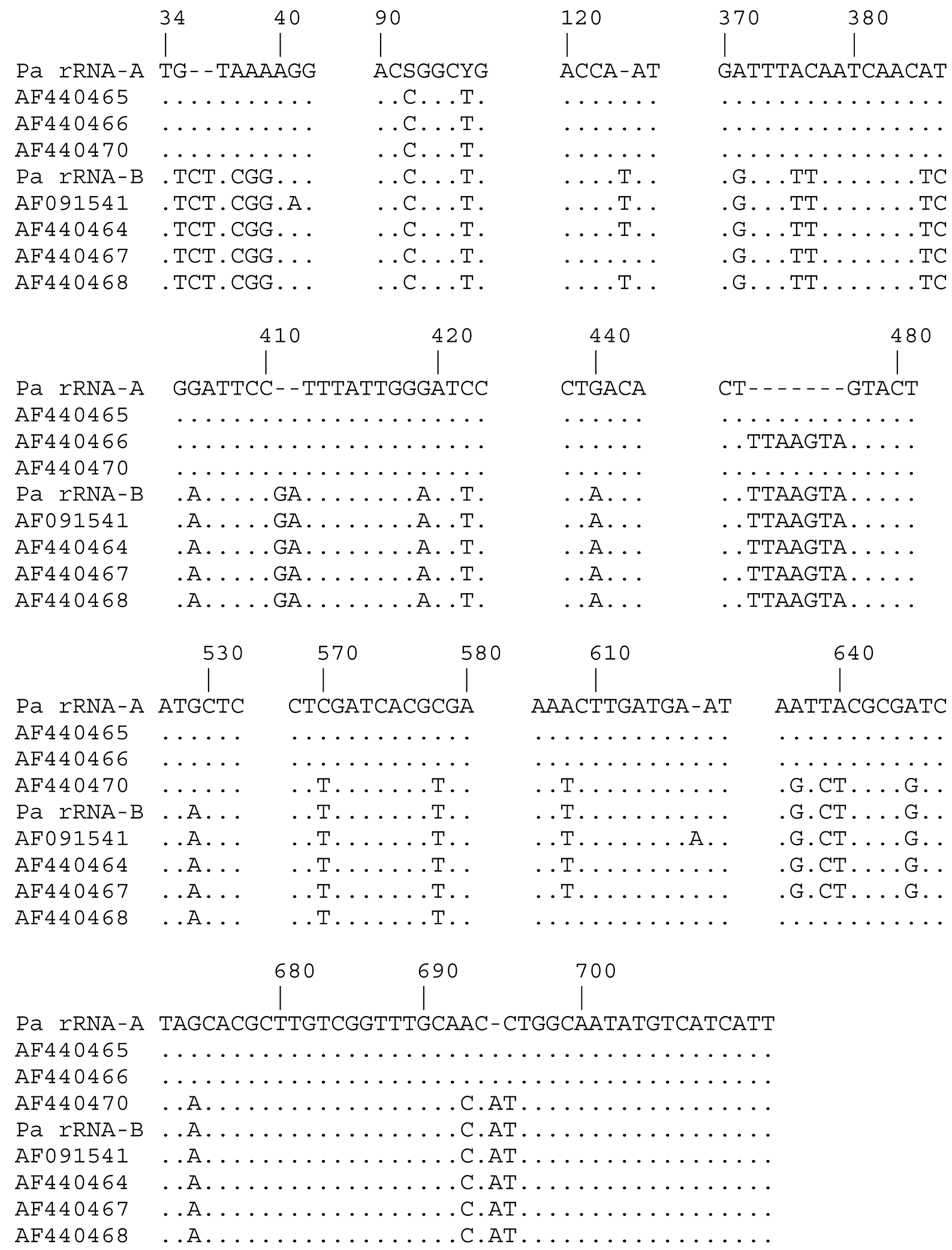

Fig. 3. Sequence alignment of the ITS1-5.8S-ITS2 regions of Perkinsus andrewsi (ATCC 50807), P. chesapeaki (isolate G117), a Perkinsus species isolated from Mya arenaria (ATCC 50864), and a Perkinsus species isolated from Tagelus plebeius (ATCC 50866) using ClustalW. Only the regions where differences occur are depicted. The numbers represent nucleotide positions in the ITS1-5.8S-ITS2 sequence of the $P$. andrews $i$ rRNA-A gene unit (AF102171). Pa rRNA-A, rRNA gene unit A of P. andrewsi (AF102171); Pa rRNA-B, rRNA gene unit B of $P$. andrewsi (AY305326); AF091541, P. chesapeaki (isolate G117); AF440464, AF440465, AF440466, AF440467, ITS1-5.8S-ITS2 type a, b, c, and d sequences from the Perkinsus species isolated from M. arenaria; AF440468, AF440470, ITS1-5.8S-ITS2 type a and c sequences from the Perkinsus species isolated from T. plebeius. The type b and d sequences of the T. plebeius isolate (AF440469 and AF440471) that are identical to the type $\mathrm{b}$ and a sequences of the M. arenaria isolate (AF440465 and AF440464), respectively, are not depicted. 


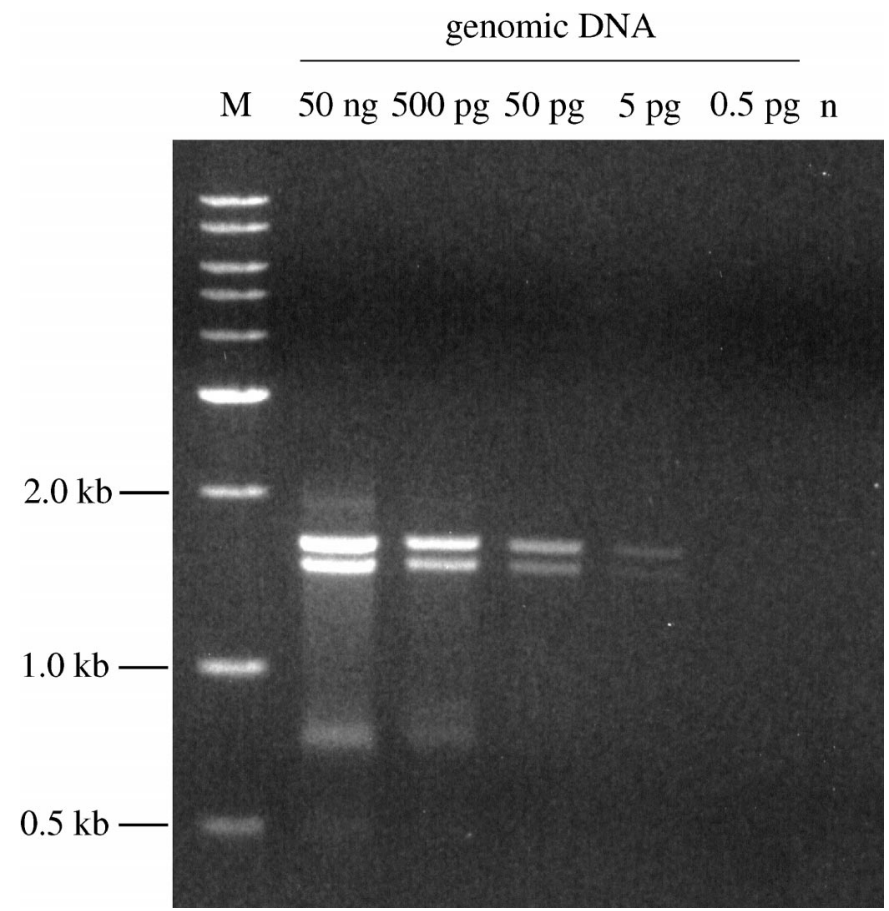

Fig. 4. Agarose gel of PCR-amplified products with IGS primers using optimized conditions. Decreasing amounts of Perkinsus andrewsi genomic DNA (50 ng to $0.5 \mathrm{pg}$ ) were used to assess the relative representation of the two intergenic spacers. n, negative control, PCR reaction contained the same mixture as the other PCR reactions except DNA was substituted with sterile distilled water; M, $1 \mathrm{~kb}$ DNA ladder.

(Fig. 5), confirming that each $P$. andrewsi cell contains both IGS sequences.

Intraclonal variability of IGS in $\boldsymbol{P}$. andrewsi. A total of 12 clones containing IGS-A sequences and nine clones containing IGS-B sequences obtained from five independent PCR amplifications were sequenced. Within the clones that had the IGS-A sequence, variability occurred at three positions. Three clones had an insertion-deletion at position 573 that was preceded by a stretch of eight $\mathrm{A}$, whereas the remaining clones had an additional $\mathrm{A}$ at this position. Transitions from $\mathrm{T}$ to $\mathrm{C}$ occurred in three clones at position 1,038, and from $\mathrm{C}$ to $\mathrm{T}$ in two clones at position 1,047. A consensus IGS-A sequence of the 12 clones was deposited in GenBank (AY305328). All 12 clones, however, differed in nine positions $(0.7 \%)$ to the previously described IGS-A (AF102171). Changes were transitions from $A$ to $G$ (four positions) and $T$ to $C$ (five positions). Sequence alignment of the IGS-A and IGS-B showed that the IGS-A was identical to IGS-B in these positions (data not shown). The IGS-B sequences of all nine clones analyzed were identical.

Southern analysis. To confirm the presence of the additional rRNA gene unit in the $P$. andrewsi genome, BamHI, BstEII, EcoRI, and ScaI restriction digests of $P$. andrewsi genomic DNA, undigested $P$. marinus genomic DNA, and plasmids containing the IGS-A and IGS-B respectively, were blotted and hybridized with probes specific for the IGS-A, IGS-B, and a probe designed to detect presumably IGSs of all Perkinsus species (Fig. 6). The IGS-A specific probe hybridized strongly with fragments of about $3.3 \mathrm{~kb}, 8.0 \mathrm{~kb}, 5.5 \mathrm{~kb}$, and $1.1 \mathrm{~kb}$ in the BamHI, BstEII, EcoRI, and ScaI digested P. andrewsi genomic DNA, respectively (Fig. 6 A). Additional weak hybridization was observed with fragments of $4.5 \mathrm{~kb}$ and $3.8 \mathrm{~kb}$ as well as
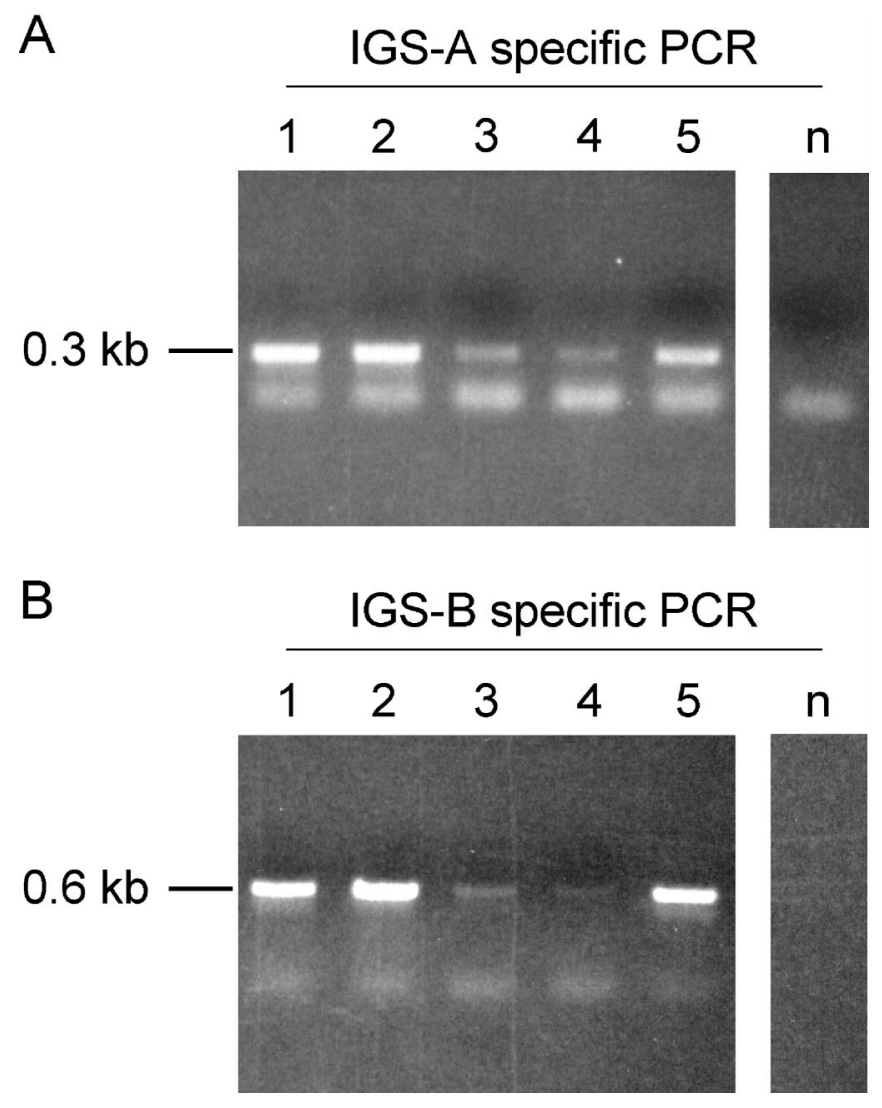

Fig 5. Agarose gels of amplified products of the single cell PCR experiment. IGS-A specific primers (A) and IGS-B specific primers (B) were used to verify the multiple IGS-amplicons obtained from single cells (1-5); n, negative control, PCR reaction contained the same mixture as the other PCR reactions except DNA was substituted with sterile distilled water.

with $4.9 \mathrm{~kb}$ and $4.0 \mathrm{~kb}$ fragments in the BstEII and EcoRI digested $P$. andrewsi DNA respectively (Fig. 6 A). The IGSA-specific probe hybridized very weakly with plasmid containing the IGS-B $(200 \mathrm{ng})$ but did not hybridize with $P$. marinus DNA, (4 $\mu \mathrm{g}$; no signal was detected after an 18-h exposure at $-80{ }^{\circ} \mathrm{C}$ ) (Fig. $6 \mathrm{~A}$ ). The IGS-B-specific probe strongly hybridized with fragments of approximately $8.0 \mathrm{~kb}, 3.0 \mathrm{~kb}$, and $0.9 \mathrm{~kb}$ in the restriction-digested $P$. andrewsi DNA, but only hybridized very weakly with 20 ng DNA with a plasmid containing the IGS-A (200 ng) and did not hybridize with $P$. marinus DNA (4 $\mu \mathrm{g})$ (Fig. $6 \mathrm{~B}$ ). These results revealed the specificity of the probes to the IGS-A and IGS-B. The probe specific for Perkinsus species IGSs (probe PER) hybridized with two fragments of approximately $8.0 \mathrm{~kb}$ and $3.3 \mathrm{~kb}$ in the Bam $\mathrm{HI}$ digested $P$. andrewsi DNA, with one fragment of $8.0 \mathrm{~kb}$ in the BstEII digested $P$. andrewsi DNA, three fragments of approximately $5.5 \mathrm{~kb}, 3.0 \mathrm{~kb}$, and $1.8 \mathrm{~kb}$ in the EcoRI digested $P$. andrewsi DNA, and with two fragments of $6.5 \mathrm{~kb}$ and $2.9 \mathrm{~kb}$ in the ScaI digested P. andrewsi DNA (Fig. 6 C). Probe PER hybridized strongly with both plasmids, and somewhat weaker with $P$. marinus genomic DNA. A stronger signal with $P$. marinus genomic DNA was obtained by a longer exposure $(18 \mathrm{~h})$ of the autoradiographic film (Fig. $6 \mathrm{C}$ ). The banding patterns observed with the three probes were consistent with fragments predicted from the rRNA-A and rRNA-B sequences (Fig. 7), with the exception of additional weak hybridizations of probe 


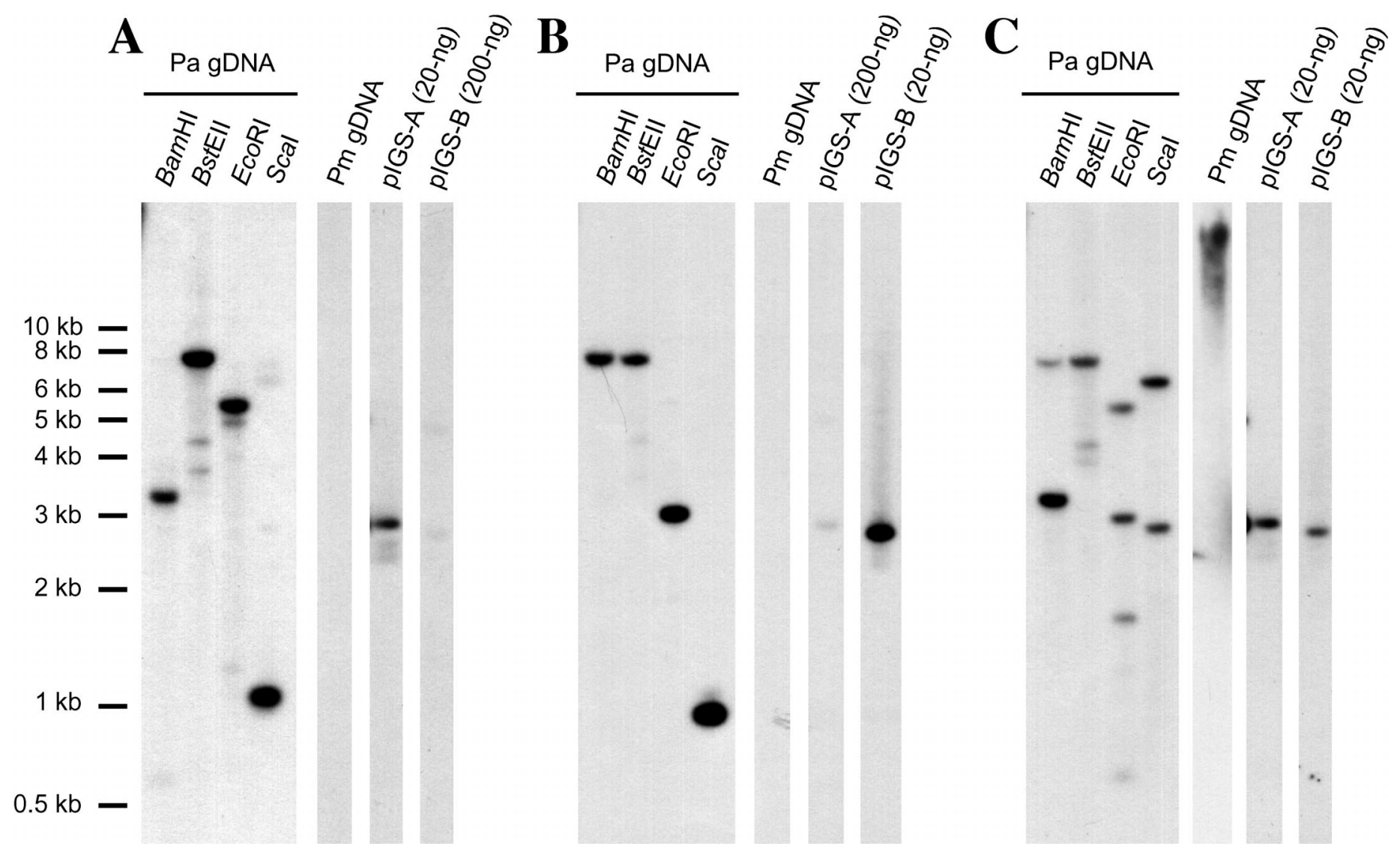

Fig. 6. Southern analysis of Perkinsus andrewsi genomic DNA. Perkinsus andrewsi genomic DNA, digested with BamHI, BstEII, EcoRI, and ScaI was size seperated on a $0.8 \%$ agarose gel, blotted onto a Hybond XL nylon membrane (Amersham Bioscience) and hybridized with an IGSA specific probe (A), an IGS-B specific probe (B), and with a probe specific to Perkinsus species IGSs (C). Undigested P. marinus genomic DNA $(4 \mu \mathrm{g})$ and 20 or $200 \mathrm{ng}$ of plasmid DNA containing the IGS-A and IGS-B were used as controls. Autoradiographic films have been exposed to the nylon membrane for $30 \mathrm{~min}$ at room temperature $(\mathbf{A}), 3 \mathrm{~h}$ at $-80^{\circ} \mathrm{C}(\mathbf{B})$, and $1 \mathrm{~h}$ at room temperature $(\mathbf{C})$, except for the autoradiographic films showing the $P$. marinus genomic DNA that have been exposed for $18 \mathrm{~h}$ at $-80{ }^{\circ} \mathrm{C}$. IGS, intergenic spacer; Pa gDNA, $P$. andrewsi genomic DNA; Pm gDNA, P. marinus genomic DNA, uncut; pIGS-A, plasmid containing the IGS-A; pIGS-B, plasmid containing the IGS-B.

A and PER with the BstEII and EcoRI digests of $P$. andrewsi DNA (Fig. 6 A, C).

\section{DISCUSSION}

The PCR amplification of $P$. andrewsi genomic DNA using primers that anneal to conserved regions of the 5S and the SSU resulted in two distinct amplicons representing IGS sequences (IGS-A and IGS-B). These were confirmed by the presence of of the $5 \mathrm{~S}$ and the SSU gene flanking sequences. The sequence of the IGS-A was identical to the previously described $P$. andrewsi IGS (Coss et al. 2001), except in nine positions. Because the IGS-A sequence described in this study represents a consensus sequence of 12 clones obtained from five independent PCR reactions, these differences most likely represent intraclonal IGS sequence variability (see below). The IGS-B, however, differed considerably from the IGS-A. Using primers specific to the IGS-B sequence and IGS-A specific primers from Coss et al. (2001), the presence of both IGS sequences in a single $P$. andrewsi cell was confirmed. Single cells were iso- lated by the "limiting dilution"' method, routinely used for subcloning of Perkinsus cultures. Although for the single cell PCR assay, serial dilutions were carried out in distilled water to facilitate concentration of the DNA at the following step, we have experimentally demonstrated by using neutral red and $4^{\prime}, 6^{\prime}$ diamidino-2-phenylindole (DAPI) that during the time that it takes to complete the procedure, the nucleus and nuclear DNA are retained (WTP and GRV unpubl.). Therefore, since the IGS$\mathrm{A}$ and $-\mathrm{B}$ specific primers target sequences in the non-transcribed spacer region of the IGS, potential cross-contamination is highly unlikely. Variability of amplicon intensities may have been due to differences in DNA yields by the crude DNA extraction procedure used. Alternatively, the different cells could be in different stages of the cell cycle and thus might contain more than one genome equivalent.

We observed no intraclonal sequence variability within the IGS-B and only low sequence variability within the IGS-A, strongly suggesting that $P$. andrewsi possesses two distinct IGS sequences.

Fig. 7. Predicted restriction map of two Perkinsus andrewsi rRNA gene units digested with BamHI, BstEII, EcoRI, and ScaI and the fragments created by these endonucleases. A. Perkinsus andrewsi rRNA-A; B. P. andrewsi rRNA-B. The hybridization sites of probe A ( $\triangle$ ), probe B ( $\mathbb{\nabla})$, and probe PER $(\mathbf{\nabla})$ are indicated. ISC-A, intercluster spacer of the rRNA-A gene unit; ICS-B, intercluster spacer of the rRNA-A gene unit. 

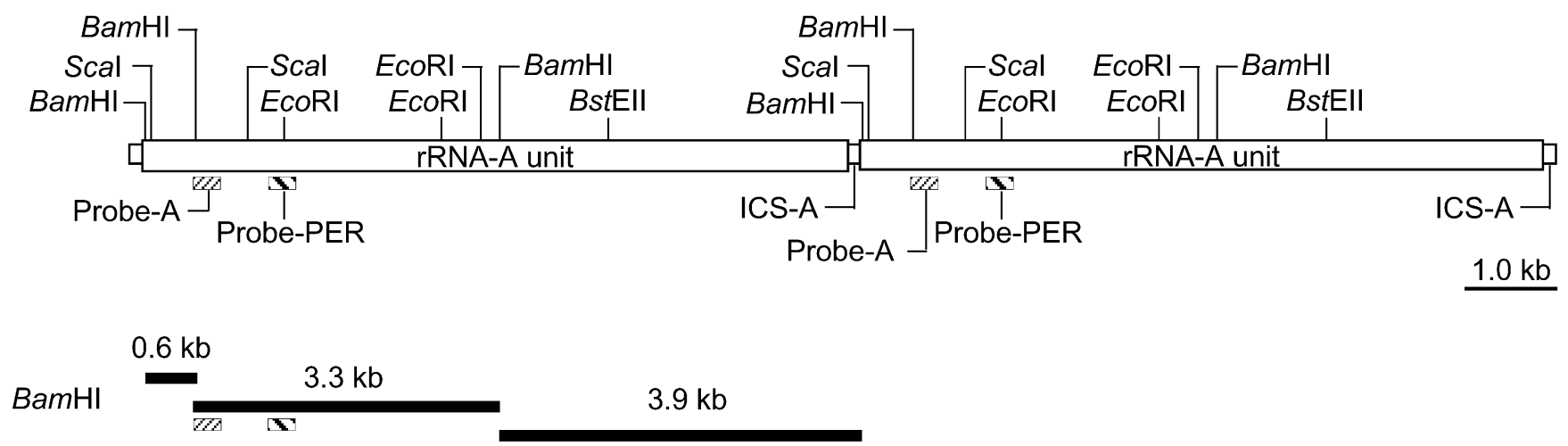

BstEll

$7.8 \mathrm{~kb}$

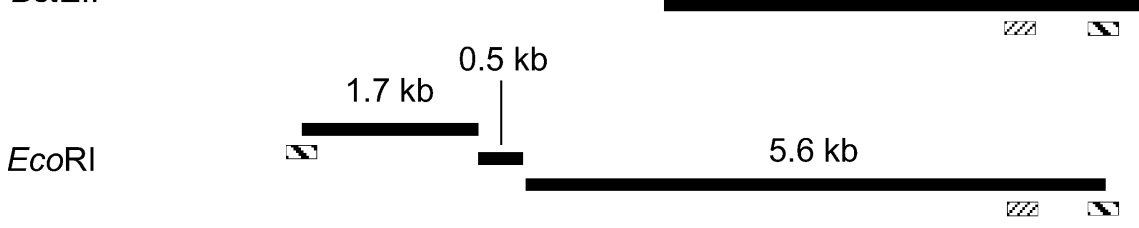

Scal $\frac{1.0 \mathrm{~kb}}{\pi \mathrm{c}} \quad 6.8 \mathrm{~kb}$

$\checkmark$

B

Perkinsus andrewsi rRNA-B

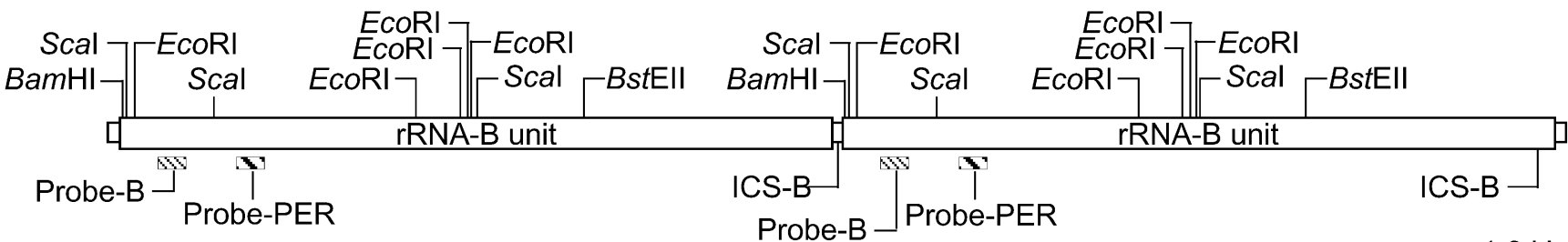

$7.7 \mathrm{~kb}$

BamHI

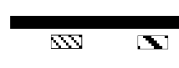

BstEll

$7.7 \mathrm{~kb}$

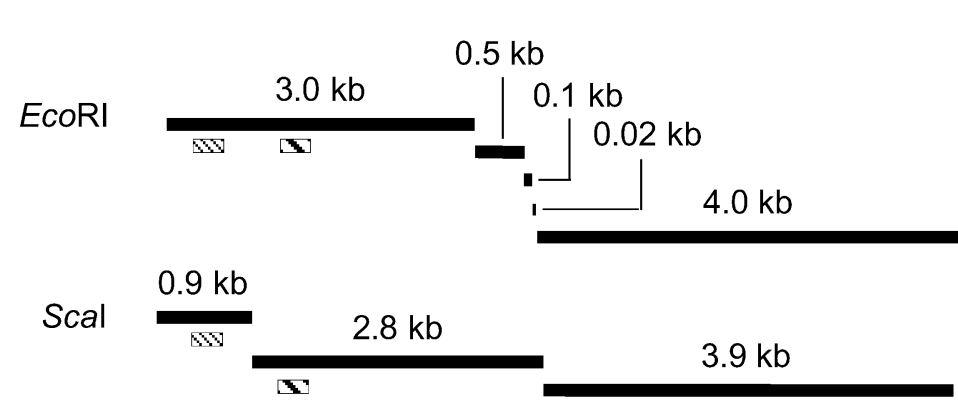


There are at least two possible organizations of the two IGS sequences within the $P$. andrewsi rRNA gene cluster(s). In one model, both IGS-A and IGS-B could be randomly dispersed and associated with identical rRNA genes, resulting in rRNA gene units that only differ in their IGSs. Alternatively, $P$. andrewsi could possess two distinct rRNA gene units, containing either IGS-A or IGS-B associated with different rRNA genes and intergenic regions. To address this question, amplicons obtained by PCR using an IGS-B-specific primer and conserved primers located in the $3^{\prime}$ end of the SSU or in the $5^{\prime}$ end of the LSU were cloned and sequenced. In all clones the IGS-B sequences were associated with rRNA genes and intergenic regions that differed in their sequences from the previously described rRNA genes and intergenic regions associated with the IGS-A. Results from Southern analysis also corroborated the presence of two distinct rRNA units in the $P$. andrewsi genome. Hybridization patterns of restriction digests of $P$. andrewsi genomic DNA were consistent with restriction length fragment polymorphisms predicted on the basis of two distinct rRNA gene units being present in a single cell. Weak hybridizations observed in some digests tested with the IGS-A-specific probe and the probe specific to Perkinsus species IGS could represent intraclonal variability either in the rRNA-A gene unit, especially in the IGS-A, or alternatively, in the $5^{\prime}$ or $3^{\prime}$ end sequences of the rRNA gene clusters. Lack of sufficient sequence information upstream or downstream of the rRNA gene clusters prevents us from confirming either alternative.

Taken together, these observations provide strong evidence that $P$. andrewsi contains two distinct rRNA gene units, which we designated as rRNA-A and rRNA-B. Further, Southern analysis and PCR suggest that each rRNA gene unit is arranged as a "head-to-tail" tandem repeat. All three probes hybridized with only one fragment in genomic DNA samples that have been digested with BstEII, an endonuclease that cuts once in each rRNA gene unit (based on restriction maps on the complete rRNA sequences). The observed fragments are slightly smaller than $8.0 \mathrm{~kb}$, which corresponds approximately to the length of each rRNA gene unit $(7.8 \mathrm{~kb}$ for the rRNA-A gene unit, and $7.7 \mathrm{~kb}$ for the rRNA-B gene unit). The presence of multiple distinct rRNA gene units has been described in vertebrates (Cortadas and Pavon 1982), in Trypanosoma cruzi (Souto and Zingales 1993), in the dinoflagellate Alexandrium (Scholin, Anderson, and Sogin 1993; Scholin et al. 1994; Yeung et al. 1996), and in the apicomplexans Theileria (Bishop et al. 2000), Babesia (Dalrymple 1990; Reddy et al. 1991), Cryptosporidium (Le Blancq et al. 1997), and Plasmodium (reviewed by McCutchan et al. 1995). In most Plasmodium species examined so far, four rRNA gene units (A, B, C, and D) have been described, with the exception of $P$. falciparum that carries seven rRNA gene units (Carlton et al. 2002; Dame and McCutchan 1984; Gardner et al. 2002; Waters 1994; Waters et al. 1997; Wellems et al. 1987). The gene units transcribe at least two distinct ribosomal types (A and S) that are stage-specifically expressed (Dame and McCutchan 1984; Waters 1994; Waters et al. 1997; Wellems et al. 1987). Sequence comparison showed that high percent identities are found between rRNA gene units that transcribe for the same rRNA types (McCutchan et al. 1995). rRNA gene units that transcribe for the different ribosomal types show less percent identity. In P. berghei for example, sequence analysis of the SSU-A and SSU-C showed that both genes are $96.5 \%$ identical (Gunderson, McCutchan, and Sogin 1986; Gunderson et al. 1987).

Based on the structural differences postulated for the different life stage-specific expressed ribosome types in Plasmodium species, it has been proposed that these ribosome types are also functionally different (Gunderson et al. 1987; Rodgers et al.
1996; Thompson et al. 1999) and that the parasite relies on functional distinct ribosomes to complete its life cycle in a mammalian and insect host (Gunderson et al. 1987). However, a recent study showed that in $P$. berghei the rRNA genes encoded by the respective gene units do not differ in the sequence of important core regions and thus lack structural differences, and both ribosome types, A and S, are expressed in life stages in the insect vector (van Spaendonk et al. 2001). The observations in $P$. berghei question the presence of functional different ribosomal types and their proposed requirement for completion of the life cycle. Instead, based on the atypical organization of the rRNA gene, van Spaendonk et al. (2001) proposed that each unit is controlled by different promoters, an arrangement that would enable the parasite to adjust the production of ribosomes depending on the need.

In $P$. andrewsi, genes of the rRNA-A and -B units show a high degree of identity: SSU-A and -B show $99.8 \%$ identity, LSU-A and -B 99.1\% identity, the 5S-A and -B 99.2\% identity, and the $5.8 \mathrm{~S} 100.0 \%$ identity, suggesting that the two units do not transcribe structural and functional distinct ribosomal types. However, the IGSs of rRNA-A and -B units show only $72.7 \%$ identity. The IGS carries all elements required for transcription and termination of the RNA genes, and is critical for the regulation of the rDNA metabolism (De Lucchini, Andronico, and Nardi 1997; Reeder 1990; Sollner-Webb and Mougey 1991). In contrast to $P$. atlanticus and $P$. marinus, which possess a single rRNA gene unit type (Robledo et al. 2002; JAFR and GRV, unpubl.), $P$. andrewsi has two distinct rRNA gene units. Whether these units are selectively regulated, as proposed for $P$. berghei (van Spandonk et al. 2001), remains to be demonstrated.

The two different rRNA gene units could be attributed to the presence of different alleles. Although the ploidy status of Perkinsus species has not yet been resolved, it has been suggested that $P$. marinus trophozoites are diploid (Reece, Bushek, and Graves 1997; Reece et al. 2001). Assuming that this is correct and that it can be extended to $P$. andrewsi, it is possible that: (a) the $P$. andrewsi monoclonal culture is heterozygous for the rRNA units; (b) both rRNA unit types are contiguously located on the same chromosome; or (c) the rRNA unit types are located on different chromosomes. Evidence suggests that Perkinsus species have multiple copies of rRNA gene units (de la Herrán et al. 2000). Hence, until further investigations are conducted to address the linkage of the two rRNA units, how these are localized and organized within the rRNA array(s) remains an open question.

The presence of multiple distinct rRNA gene units in a single Perkinsus species adds new complexity to the use of rRNA sequences for taxonomic analysis and species designations based on molecular characters. It also underscores the need of rigorous characterization of the complete rRNA gene locus sequences to determine whether polymorphisms observed in intergenic regions represent inter- or intraclonal variability or, as in the case for $P$. andrewsi, represent distinct rRNA gene units. This study shows low sequence variability within the IGS of each rRNA gene unit of $P$. andrewsi. Only $0.7 \%$ variability was observed in the IGS-A sequence, and none for the IGS-B. In $P$. marinus, two distinct sequence types (type I and II) differing in only seven nucleotide positions out of $307 \mathrm{bp}$ within the nontranscibed spacer of the IGS were identified (Robledo et al. 1999), suggesting that in this species the IGS also has a low degree of sequence variability.

In a recent study, Dungan et al. (2002) reported intraclonal variability of ITS sequences in clonal cultures of Perkinsus species isolated from $M$. arenaria and $T$. plebeius. Four variant ITS1-5.8S-ITS2 types ("a" to " d'") were described. Sequence 
comparison of the eight sequences with $P$. andrewsi A and $\mathrm{B}$ unit ITS-5.8S-ITS2 sequences show that the type "a" of the $M$. arenaria isolate and type " $\mathrm{d}$ " of the $T$. plebeius isolate are identical to the ITS1-5.8S-ITS2-B sequences of $P$. andrewsi. Similarly, the type " $b$ " of both isolates is identical to the rRNA-A ITS1-5.8S-ITS2 sequence of $P$. andrewsi. The remaining two types of each isolate appear to be intermediate, sharing sequences with the $P$. andrewsi A and B unit, respectively. Dungan et al. (2002) obtained the ITS1-5.8S-ITS2 sequences by PCR amplification using conserved primers, which has the potential to produce sequence artifacts by in vitro recombination, and thus, may mislead genetic analysis (Meyerhans, Vartanian, and Wain-Hobson 1990; Judo, Wedel, and Wilson 1998; Tanabe et al. 2002). Tanabe et al. (2002) analyzed PCR amplifications of a low copy gene (Mspl) from different $P$. falciparum strains, and observed up to $11.5 \%$ in vitro recombination when conserved primers were used. In vitro recombination sequence artifacts can be avoided by either sequencing the genes of interest directly from digested genomic DNA, or by the use of at least one allele-specific primer (Tanabe et al. 2002). We chose the second approach and used either rRNAA- or rRNA-B-specific primers in combination with a conserved primer to amplify partial rRNA sequences that contain the ITS1-5.8S-ITS2 region. No in vitro recombination was observed with this system, but if primers based on conserved regions were used to co-amplify partial A and B type rRNA sequences, sequence "chimeras" were identified (data not shown).

Sequence comparison of the two rRNA units of $P$. andrewsi and $P$. chesapeaki, a Perkinsus species isolated from $M$. arenaria, revealed that the SSU-B gene and the ITS1-5.8-ITS2-B sequence have high percent identity to the respective sequences of $P$. chesapeaki, suggesting that $P$. chesapeaki and $P$. andrewsi are closely related. However, in $P$. chesapeaki only one rRNA gene unit was described, and no intraclonal variability has been reported (Kotob et al. 1999). For the Perkinsus isolates from $M$. arenaria and $T$. plebeius, only partial rRNA sequences have been characterized. Characterization of the complete rRNA gene loci from these isolates and from the $P$. chesapeaki holotype (McLaughlin et al. 2000), currently unavailable, would reveal whether the observed sequence polymorphisms represent either the presence of distinct rRNA gene units or variability within a single unit. Furthermore, it would confirm the presence of the intermediate forms described, and contribute to resolve the relationship between $P$. andrewsi, $P$. chesapeaki, and the Perkinsus isolates from $M$. arenaria and $T$. plebeius.

A preliminary search in $P$. marinus and $P$. atlanticus by PCR, the two other Perkinsus species from which the complete rRNA locus has been characterized, failed to reveal the presence of additional rRNA gene units (Robledo et al. 2002; JAFR and GRV, unpublished). Thus, in this regard, the $P$. andrewsi holotype appears to be unique among the Perkinsus species characterized at present time.

\section{ACKNOWLEDGMENTS}

This work was supported by DOC Cooperative Agreements No. NA47FL-0163, NA57FL-0039 and NA90AA-D-SG063 awarded by NOAA, Oyster Disease Research Program, Sea Grant College to GRV. We thank Dr. Eric J. Schott for helpful suggestions about Southern analysis.

\section{LITERATURE CITED}

Altschul, S. F., Gish, W., Miller, W., Myers, E. W. \& Lipman, D. J. 1990. Basic local alignment search tool. J. Mol. Biol., 215:403-410. Bishop, R., Gobright, E., Spooner, P., Allsopp, B., Sohanpal, B. \& Collins, N. 2000. Microsequence heterogeneity and expression of the
LSU rRNA genes within the two single copy ribosomal transcription units of Theileria parva. Gene, 257:299-305.

Brown, T. 1993. Hybridization analysis of DNA blots. In: Ausubel, F. A., Brent, R. Kingston, R. E., Moore, Seidman, J. G., Smith, J. A. \& Struhl, K. (ed.), Current Protocols in Molecular Biology. John Wiley \& Sons, New York. p. 2.10.1-2.10.16.

Brugerolle, G. 2002. Cryptophagus subtilis: a new parasite of cryptophytes affiliated with the Perkinsozoa lineage. Eur. J. Protistol., 37: 379-390.

Carlton, J. M., Angiuoli, S. V., Suh, B. B., Kooij, T. W., Pertea, M. Silva, J. C., Ermolaeva, M. D., Allen, J. E., Selengut, J. D., Koo, H. L., Peterson, J. D., Pop, M., Kosack, D. S., Shumway, M. F., Bidwell, S. L., Shallom, S. J., van Aken, S. E., Riedmuller, S. B., Feldblyum, T. V., Cho, J. K., Quackenbush, J., Sedegah, M., Shoaibi, A., Cummings, L. M., Florens, L., Yates, J. R., Raine, J. D., Sinden, R. E., Harris, M. A., Cunningham, D. A., Preiser, P. R., Bergman, L. W., Vaidya, A. B., van Lin, L. H., Janse, C. J., Waters, A. P., Smith, H. O., White, O. R., Salzberg, S. L., Venter, J. C., Fraser, C. M., Hoffman, S. L., Gardner, M. J. \& Carucci, D. J. 2002. Genome sequence and comparative analysis of the model rodent malaria parasite Plasmodium yoelii yoelii. Nature, 419:512-519.

Cortadas, J. \& Pavon, M. C. 1982. The organization of ribosomal genes in vertebrates. $E M B O$ J., 1:1075-1080.

Coss, C. A., Robledo, J. A. F. \& Vasta, G. R. 2001. Fine structure of clonally propagated in vitro life stages of a Perkinsus sp. isolated from the Baltic clam Macoma balthica. J. Eukaryot. Microbiol., 48: $38-51$.

Coss, C. A., Robledo, J. A. F, Ruiz, G. M. \& Vasta, G. R. 2001. Description of Perkinsus andrewsi n. sp. isolated from the Baltic clam (Macoma balthica) by characterization of the ribosomal RNA locus, and development of a species-specific PCR-based diagnostic assay. J. Eukaryot. Microbiol., 48:52-61.

Dalrymple, B. P. 1990. Cloning and characterization of the rRNA genes and flanking regions from Babesia bovis: use of the genes as straindiscriminating probes. Mol. Biochem. Parasitol., 43:117-124.

Dame, J. B. \& McCutchan, T. F. 1983. The four ribosomal DNA units of the malaria parasite Plasmodium berghei. Identification, restriction map, and copy number analysis. J. Biol. Chem., 258:6984-6990.

Dame, J. B. \& McCutchan, T. F. 1984. Identification of $5 \mathrm{~S}$ and $5.8 \mathrm{~S}$ ribosomal RNA molecules and their genes in Plasmodium berghei. Mol. Biochem. Parasitol., 11:301-307.

de la Herrán, R., Garrido-Ramos, M. A., Navas, J. I., Ruiz Rejón, C. \& Ruiz Rejón, M. 2000. Molecular characterization of the ribosomal RNA gene region of Perkinsus atlanticus: its use in phylogenetic analysis and as a target for a molecular diagnosis. Parasitology, 120: 345-353.

De Lucchini, S., Andronico, F. \& Nardi, I. 1997. Molecular structure of the rDNA intergenic spacer (IGS) in Triturus: implications for the hypervariability of rDNA loci. Chromosoma, 106:315-326.

Dungan, C. F., Hamilton, R. M., Hudson, K. L., McCollough, C. B. \& Reece, K. S. 2002. Two epizootic diseases in Chesapeake Bay commercial clams, Mya arenaria and Tagelus plebeius. Dis. Aquat. Org., 50:67-78.

Fong, D., Rodriguez, R., Koo, K., Sun, J., Sogin, M. L., Bushek, D., Littlewood, D. T. \& Ford, S. E. 1993. Small subunit ribosomal RNA gene sequence of the oyster parasite Perkinsus marinus. Mol. Mar. Biol. Biotechnol., 2:346-350.

Gardner, M. J., Hall, N., Fung, E., White, O., Berriman, M., Hyman, R. W., Carlton, J. M., Pain, A., Nelson, K. E., Bowman, S., Paulsen, I. T., James, K., Eisen, J. A., Rutherford, K., Salzberg, S. L., Craig, A., Kyes, S., Chan, M. S., Nene, V., Shallom, S. J., Suh, B., Peterson, J., Angiuoli, S., Pertea. M., Allen, J., Selengut, J., Haft, D., Mather, M. W., Vaidya, A. B., Martin, D. M., Fairlamb, A. H., Fraunholz, M. J., Roos, D. S., Ralph, S. A., McFadden, G. I., Cummings, L. M., Subramanian, G. M., Mungall, C., Venter, J. C., Carucci, D. J., Hoffman, S. L., Newbold, C., Davis, R. W., Fraser, C. M. \& Barrell, B. 2002. Genome sequence of the human malaria parasite Plasmodium falciparum. Nature, 419:498-511.

Gauthier, J. D. \& Vasta, G. R. 1995. In vitro culture of the eastern oyster parasite Perkinsus marinus: optimization of the methodology. J. Invertebr. Pathol., 66:156-168.

Goggin, C. L. 1994. Variation in the two internal transcribed spacers and 5.8S ribosomal RNA from five isolates of the marine parasite 
Perkinsus (Protista, Apicomplexa). Mol. Biochem. Parasitol., 65: 179-182.

Goggin, C. L. \& Barker, S. C. 1993. Phylogenetic position of the genus Perkinsus (Protista, Apicomplexa) based on small subunit ribosomal RNA. Mol. Biochem. Parasitol., 60:65-70.

Green, E. D. 1997. Genome Analysis: a Laboratory Manual. Cold Spring Harbor Laboratory Press, Plainview, New York.

Guay, J. M., Huot, A., Gagnon, S., Tremblay, A. \& Levesque, R. C. 1992. Physical and genetic mapping of cloned ribosomal DNA from Toxoplasma gondii: primary and secondary structure of the $5 \mathrm{~S}$ gene. Gene, 114:165-171.

Gunderson, J. H., McCutchan, T. F. \& Sogin, M. L. 1986. Sequence of the small subunit ribosomal RNA gene expressed in the bloodstream stages of Plasmodium berghei: evolutionary implications. J. Protozool., 33:525-529.

Gunderson, J. H., Sogin, M. L., Wollett, G., Hollingdale, M., de la Cruz, V. F., Waters, A. P. \& McCutchan, T. F. 1987. Structurally distinct, stage-specific ribosomes occur in Plasmodium. Science, 238:933937.

Judo, M. S., Wedel, A. B. \& Wilson, C. 1998. Stimulation and suppression of PCR-mediated recombination. Nucleic Acids Res., 26: 1819-1825.

Kawai, H., Muto, H., Fujii, T. \& Kato, A. 1995. A linked 5S rRNA gene in Scytosiphon lomentaria (Scytosiphonales, Phaeophyceae). J. Phycol., 31:306-311.

Kotob, S. I., McLaughlin, S. M., van Berkum, P. \& Faisal, M. 1999. Characterization of two Perkinsus spp. from the softshell clam, Mya arenaria using the small subunit ribosomal RNA gene. J. Eukaryot. Microbiol., 46:439-444.

Kuvardina, O. N., Leander, B. S., Aleshin, V. V., Myl'nikov, A. P., Keeling, P. J. \& Simdyanov, T. G. 2002. The phylogeny of colpodellids (Alveolata) using small subunit rRNA gene sequences suggests they are the free-living sister group to apicomplexans. J. Eukaryot. Microbiol., 49:498-504.

Le Blancq, S. M., Khramtsov, N. V., Zamani, F., Upton, S. J. \& Wu, T. W. 1997. Ribosomal RNA gene organization in Cryptosporidium parvum. Mol. Biochem. Parasitol., 90:463-478.

Levine, N. D. 1978. Perkinsus gen. n. and other new taxa in the protozoan phylum Apicomplexa. J. Parasitol., 64:549.

Mackin, J. G., Owen, H. M. \& Collier, A. 1950. Preliminary note on the occurrence of a new protistan parasite, Dermocystidium marinum n. sp. in Crassostrea virginica (Gmelin). Science, 111:328-329.

Marsh, A. G., Gauthier, J. D. \& Vasta, G. R. 1995. A semiquantitative PCR assay for assessing Perkinsus marinus infections in the eastern oyster, Crassostrea virginica. J. Parasitol., 81:577-583.

McCutchan, T. F., Li, J., McConkey, G. A., Rogers, M. J. \& Waters, A. P. 1995. The cytoplasmic ribosomal RNAs of Plasmodium spp. Parasitol. Today, 11:134-138.

McCutchan, T. F., de la Cruz, V. F., Lal, A. A., Gunderson, J. H., Elwood, H. J. \& Sogin, M. L. 1988. Primary sequences of two small subunit ribosomal RNA genes from Plasmodium falciparum. Mol. Biochem. Parasitol., 28:63-68.

McLaughlin, S. M., Tall, B. D., Shaheen, A., Elsayed, E. E. \& Faisal, M. 2000. Zoosporulation of a new Perkinsus species isolated from the gills of the softshell clam Mya arenaria. Parasite, 7:115-122.

Medlin, L., Elwood, H. J., Stickel, S. \& Sogin, M. L. 1988. The characterization of enzymatically amplified eukaryotic 16S-like rRNAcoding regions. Gene, 71:491-499.

Meyerhans, A., Vartanian, J. P. \& Wain-Hobson S. 1990. DNA recombination during PCR. Nucleic Acids Res., 18:1687-1691.

Norén, F., Moestrup, Ø. \& Rehnstam-Holm, A.-S. 1999. Parvilucifera infectans Norén et Moestrup gen. et sp. nov. (Perkinsozoa phylum nov.): a parasitic flagellate capable of killing toxic microalgae. Eur. J. Protistol., 35:233-254.

Penna, M. S., Khan, M. \& French, R. A. 2001. Development of a multiplex PCR for the detection of Haplosporidium nelsoni, Haplosporidium costale and Perkinsus marinus in the eastern oyster (Crassostrea virginica, Gmelin, 1971). Mol. Cell Probes, 15:385-390.

Ray, S. M. 1952. A culture technique for the diagnosis of infection with Dermocystidium marinum in oysters. Science, 116:360-361.

Reddy, G. R., Chakrabarti, D., Yowell, C. A. \& Dame, J. B. 1991. Sequence microheterogeneity of the three small subunit ribosomal
RNA genes of Babesia bigemina: expression in erythrocyte culture. Nucleic Acids Res., 19:3641-3645.

Reece, K. S., Bushek, D. \& Graves, J. E. 1997. Molecular markers for population genetic analysis of Perkinsus marinus. Mol. Mar. Biol. Biotechnol., 6:197-206.

Reece, K. S., Bushek, D., Hudson, K. L. \& Graves, J. E. 2001. Geographic distribution of Perkinsus marinus genetic strains along the Atlantic and Gulf Coasts of the USA. Mar. Biol., 139:1047-1055.

Reeder, R. H. 1990. rRNA synthesis in the nucleolus. Trends Genet., 6:390-395.

Robledo, J. A. F., Coss, C. A. \& Vasta, G. R. 2000. Characterization of the ribosomal RNA locus of Perkinsus atlanticus and development of a polymerase chain reaction-based diagnostic assay. J. Parasitol., 86:972-978.

Robledo, J. A. F., Nunes, P. A., Cancela, M. L. \& Vasta, G. R. 2002. Development of an in vitro clonal culture and characterization of the rRNA gene cluster of Perkinsus atlanticus, a protistan parasite of the clam Tapes decussatus. J. Eukaryot. Microbiol., 49:414-422.

Robledo, J. A. F., Wright, A. C., Marsh, A. G. \& Vasta, G. R. 1999 Nucleotide sequence variability in the non-transcribed spacer of the rRNA locus in the oyster parasite Perkinsus marinus. J. Parasitol., 85:650-656.

Robledo, J. A. F., Gauthier, J. D., Coss, C. A., Wright, A. C. \& Vasta, G. R. 1998. Species-specificity and sensitivity of a PCR-based assay for Perkinsus marinus in the eastern oyster, Crassostrea virginica: a comparison with the fluid thioglycollate assay. J. Parasitol., 84: 1237-1244.

Rogers, M. J., Gutell, R. R., Damberger, S. H., Li, J., McConkey, G. A., Waters, A. P. \& McCutchan, T. F. 1996. Structural features of the large subunit rRNA expressed in Plasmodium falciparum sporozoites that distinguish it from the asexually expressed subunit rRNA. RNA, 2:134-145.

Saldarriaga, J. F., McEwan, M. L., Fast, N. M., Taylor, F. J. R. \& Keeling, P. J. 2003. Multiple protein phylogenies show that Oxyrrhis marina and Perkinsus marinus are early branches of the dinoflagellate lineage. Int. J. Syst. Evol. Microbiol., 53:355-365.

Sambrook, J. \& Russell, D. W. 2001. Molecular Cloning. A Laboratory Manual, 3rd ed. Cold Spring Harbor Laboratory Press, Cold Spring Harbor, New York.

Scholin, C. A., Anderson, D. M. \& Sogin, M. L. 1993. Two distinct small-subunit ribosomal RNA genes in the North American toxic dinoflagellate Alexandrium fundyense (Dinophyceae). J. Phycol., 29: 209-216.

Scholin, C. A., Herzog, M., Sogin, M. L. \& Anderson, D. M. 1994 Identification of group- and strain-specific genetic markers for globally distributed Alexandrium (Dinophyceae). 2. Sequence analysis of a fragment of the LSU rRNA gene. J. Phycol., 30:999-1011.

Siddall, M. E., Reece, K. S., Graves, J. E. \& Burreson, E. M. 1997. 'Total evidence' refutes the inclusion of Perkinsus species in the phylum Apicomplexa. Parasitology, 115:165-176.

Sollner-Webb, B. \& Mougey, E. B. 1991. News from the nucleolus: rRNA gene expression. Trends Biochem. Sci., 16:58-62.

Souto, R. P. \& Zingales, B. 1993. Sensitive detection and strain classification of Trypanosoma cruzi by amplification of a ribosomal RNA sequence. Mol. Biochem. Parasitol., 62:45-52.

Tanabe, K., Sakihama, N., Farnert, A., Rooth, I., Bjorkman, A., Walliker, D. \& Ranford-Cartwright, L. 2002. In vitro recombination during PCR of Plasmodium falciparum DNA: a potential pitfall in molecular population genetic analysis. Mol. Biochem. Parasitol., 122: 211-216.

Thompson, J. D., Higgins, D. G. \& Gibson, T. J., 1994. CLUSTAL W: improving the sensitivity of progressive multiple sequence alignment through sequence weighting, position-specific gap penalties and weight matrix choice. Nucleic Acids Res., 22:4673-4680.

Thompson, J., van Spaendonk, R. M., Choudhuri, R., Sinden, R. E., Janse, C. J. \& Waters, A. P. 1999. Heterogeneous ribosome populations are present in Plasmodium berghei during development in its vector. Mol. Microbiol., 31:253-260.

van Spaendonk, R. M., Ramesar, J., van Wigcheren, A., Eling, W., Beetsma, A. L., van Gemert, G. J., Hooghof, J., Janse, C. J. \& Waters, A. P. 2001. Functional equivalence of structurally distinct ribosomes in the malaria parasite, Plasmodium berghei. J. Biol. Chem., 276: 22638-22647. 
Waters, A. P. 1994. The ribosomal RNA genes of Plasmodium. Adv. Parasitol., 34:33-79.

Waters, A. P., van Spaendonk, R. M., Ramesar, J., Vervenne, R. A., Dirks, R. W., Thompson, J. \& Janse, C. J. 1997. Species-specific regulation and switching of transcription between stage-specific ribosomal RNA genes in Plasmodium berghei. J. Biol. Chem., 272: 3583-3589.

Wellems, T. E., Walliker, D., Smith, C. L., do Rosario, V. E., Maloy, W. L., Howard, R. J., Carter, R. \& McCutchan, T. F. 1987. A his- tidine-rich protein gene marks a linkage group favored strongly in a genetic cross of Plasmodium falciparum. Cell, 49:633-642.

Yarnall, H. A., Reece, K. S., Stokes, N. A. \& Burreson, E. M. 2000. A quantitative competitive polymerase chain reaction assay for the oyster pathogen Perkinsus marinus. J. Parasitol., 86:827-37.

Yeung, P. K., Kong, K. F., Wong, F. T. \& Wong, J. T. 1996. Sequence data for two large-subunit rRNA genes from an Asian strain of $\mathrm{Al}$ exandrium catenella. Appl. Environ. Microbiol., 62:4199-4201.

Received 06/27/03, 11/19/03; accepted 12/09/03 